\title{
Extreme rainfall, hydric conditions and associated atmospheric circulation in the southern La Plata Basin
}

\author{
Olga C. Penalba ${ }^{1,2, *}$, Juan A. Rivera ${ }^{3}$, Vanesa C. Pántano ${ }^{1,2}$, María L. Bettolli ${ }^{1,2}$ \\ ${ }^{1}$ Departamento de Ciencias de la Atmósfera y los Océanos, Facultad de Ciencias Exactas y Naturales, \\ Universidad de Buenos Aires, Intendente Güiraldes 2160, Pabellón 2, $2^{\circ}$ piso - Ciudad Universitaria, C1428EGA Buenos \\ Aires, Argentina \\ ${ }^{2}$ Consejo Nacional de Investigaciones Científicas y Técnicas (CONICET), Av. Rivadavia 1917, C1033AAJ, Buenos Aires, \\ Argentina \\ ${ }^{3}$ Instituto Argentino de Nivología, Glaciología y Ciencias Ambientales (CCT-Mendoza / CONICET), Av. Ruiz Leal s/n, \\ Parque General San Martín, 5500 Mendoza, Argentina
}

\begin{abstract}
The interaction between land surface and atmosphere plays an important role in the climate system. Soil-atmosphere feedback mechanisms are analyzed by calculating the hydric condition (HC) of the soil from the water balance. Spatial coherence between HC and the Standardized Precipitation Index (SPI) as well as the circulation patterns associated with rainfall shortages and excess was evaluated over the southern La Plata Basin, fulfilling one of the objectives of the CLARIS LPB project. Monthly precipitation, and maximum and minimum temperatures registered at 35 stations over the 1961-2008 period were used to calculate the HC and SPI indices while the characteristics of the associated circulation were derived from daily sea level pressure fields from NCEP DOE Reanalysis 2 for a domain covering South America. Our results show that the $\mathrm{HC}$ responds better to accumulated precipitation anomalies in relatively short time scales. Dry and wet months were selected based on the SPI, according to several thresholds that define the spatial extension of these events. This analysis depends on the region, indicating the diversity of dry and wet events. Nevertheless, spatial coherence between both indices was found for regional extreme events. The analysis of the circulation showed that specific daily surface circulation types contribute to wet and dry cases and have a predominant occurrence related to the climatology in the development of the extreme hydric events in the region. This research complements previous studies carried out with modeled data and shows the complexity in the propagation of the precipitation anomalies through the soil/land surface.
\end{abstract}

KEY WORDS: Precipitation extremes $\cdot$ Dry months $\cdot$ Wet months $\cdot$ Hydric condition $\cdot$ Atmospheric circulation $\cdot$ Weather types $\cdot$ La Plata Basin

\section{INTRODUCTION}

The La Plata Basin (LPB) in southern South America is a region where water resources and agricultural activities are sensitive to climate variability and change (Ereño 2011). Approximately 30\% of LPB belongs to Argentina, where the production of $>90 \%$ of the country's cereal and oilseeds, and the breeding of $>70 \%$ of the country's cattle takes place. The Humid Pampas, located to the south of the basin, are one of the largest agricultural regions in the world. In Argentina, $14.4 \%$ of the land use is agricultural (World Bank 2015) and 92\% of this area, most of it located in the LPB, consists of rainfed crops (Popescu 
et al. 2012). Extreme rainfall events can have large and widespread impacts on this agricultural environment, as well as on water availability and human society. Therefore, information on how frequently extreme conditions occur over the region is relevant for decision makers.

The frequency and/or intensity of extreme weather events, such as droughts and floods, are increasing because of climate change (IPCC 2013). During the last 2 decades, Argentina has experienced several prolonged and intense droughts (Rivera \& Penalba 2014), with widespread impacts on the agricultural and hydrological sectors and, therefore, on the economy and society of the region. These dry spells have been interrupted locally by heavy rainfall events as occurred in November 2009 at the Salto Grande Dam, located on the Uruguay river, or in February 2010 in central-eastern Argentina (Bidegain et al. 2010, 2011).

A number of studies have characterized variability and trends of extreme rainfall on regional and national scales (Castañeda \& Barros 2001, Minetti et al. 2003, Boulanger et al. 2005, Penalba \& Vargas 2008, Penalba \& Robledo 2010). These studies show that the extreme rainfall and drought events exhibit high spatial and temporal variability in the region. This could be associated with the interdecadal, interannual and intraseasonal variabilities that influence the total precipitation amounts and timing. A review of the different factors that modulate extreme precipitation events over the LPB has been made by Cavalcanti et al. (2015). Some of the factors related to extreme monthly precipitation are related to synoptic time scales. In this sense, many authors have documented the influence of daily circulation on rainfall in southern South America on a synoptic climatology (Espinoza et al. 2013, Bettolli \& Penalba 2014). Solman \& Menéndez (2003) found that cold and wet (warm and dry) local anomalies over the region are associated with a $500 \mathrm{hPa}$ anomalous ridge (trough) over the southeast Pacific and a northwest-southeast anomalous trough (ridge) downstream, with strong advection of cold (warm) air from the southeast (northeast) and a northward (southward) shift in the storm track. Bettolli \& Penalba (2014) found that the configuration of sea level pressure anomalies with the highest contribution to dry days in the central Pampas regions is a positive daily structure in the southwest of the continent centered over the Pacific Ocean. This structure, which intensifies the ridges west of the Andes and induces an anomalous advection of anticyclonic vorticity over the Humid Pampas, favors stability at the middle and low levels of the atmosphere. Barrucand et al. (2014) studied the dry months with extreme cold or warm temperature conditions over the region and analyzed how daily circulation contributed to these extreme months. Warm, dry months are related to outstanding monthly frequencies of positive daily geopotential height anomalies at $500 \mathrm{hPa}$ with a center over the Pacific Ocean/southwest of South America, causing an intensification of the westerlies to the south of $45^{\circ} \mathrm{S}$. Cold, dry months are related to a high frequency of structures with a ridge whose axis extends towards the Pacific Ocean and is related to a surface anticyclone centered over the province of Buenos Aires $\left(36^{\circ} \mathrm{S}, 60^{\circ} \mathrm{W}\right)$. A review of the synoptic features associated with the occurrence of extreme rainfall over southern South America during the first decade of the 21st century has been made by Cavalcanti (2012).

A useful index for determining precipitation shortage and excess over a variety of time scales is the Standardized Precipitation Index (SPI, McKee et al. 1993). Although the SPI was developed for defining and monitoring drought, it is also a powerful, flexible index for determining anomalously wet periods. The SPI index is simple to calculate, and has been widely used in southern South America, proving to be a good estimator of both wet and dry conditions (Seiler et al. 2002, Krepper \& Zucarelli 2010, Penalba \& Rivera 2013). Even though rainfall is the primary cause of these extreme events, rainfall data alone are frequently insufficient to assess the effect on agricultural productivity.

Different processes are involved in the interaction between land surface and atmosphere. Seneviratne et al. (2010) present an extensive review synthesizing the complexity of this interaction, including the influence over soil moisture. One way to analyze this influence is to estimate the hydric condition of the soil from the water balance. Pántano et al. (2014) employed this methodology to study the hydric response of the soil to monthly accumulated rainfall and monthly potential evapotranspiration in the Humid Pampas. They found hydric excess to the east and hydric deficit to the west, while a transition zone in the center of the region was characterized by high seasonality. Due to the impact on agriculture, a continuous monitoring of this variability is needed. Although precipitation is the most important control of water availability and its variability, a diversity of factors determine the complexity of the soil-atmosphere system. In particular, the LPB has been identified as a region where soil moisture controls some of the variability in precipitation (Sörensson \& Menéndez 2011, Ruscica et al. 2014). 


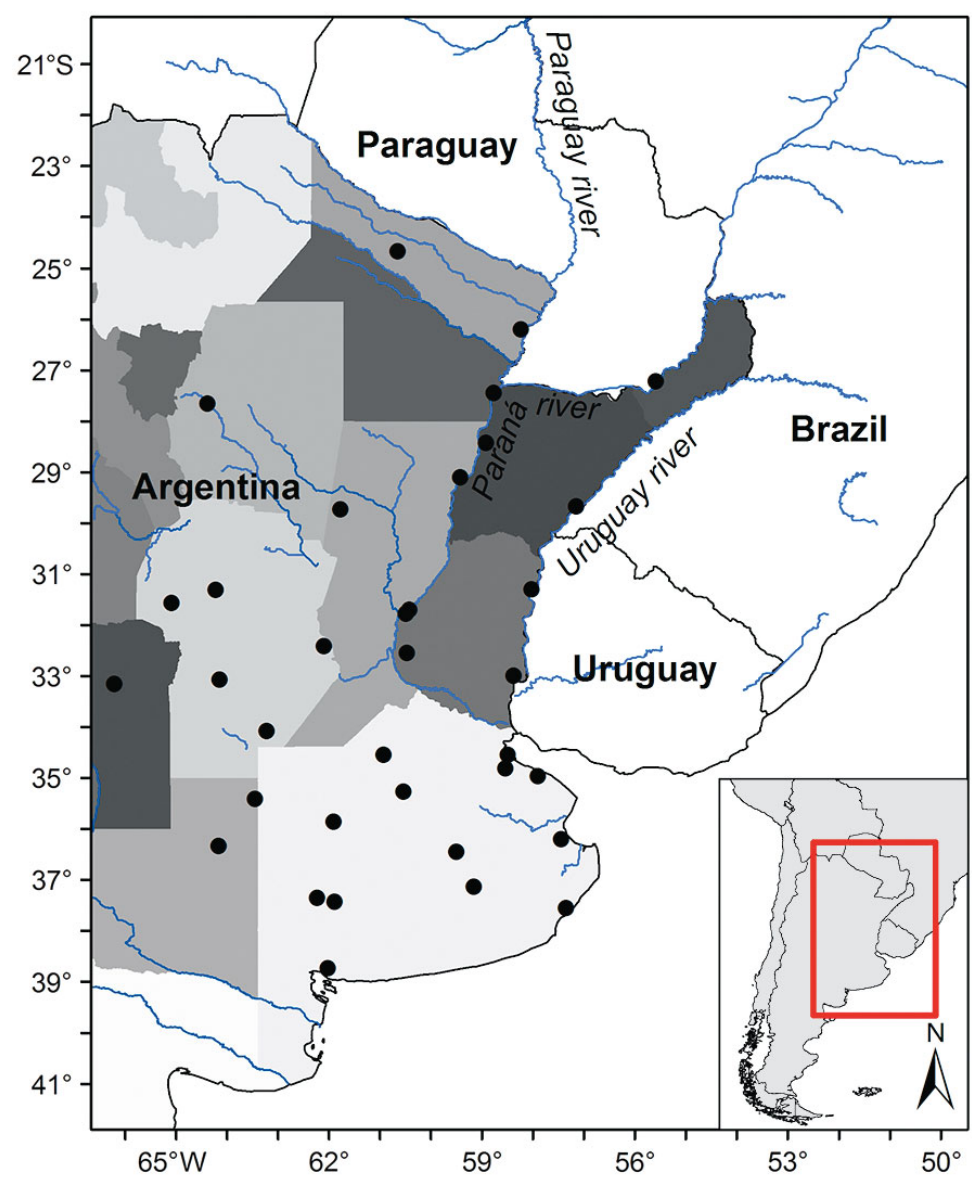

Fig. 1. Spatial distribution of the meteorological stations used in the study and river locations. Shading indicates Argentine provincial boundaries

optic features that favor the occurrence of these extreme monthly events. The results can be helpful for validating model simulations over the region and the connection between hydric condition and precipitation can be used for seasonal forecasts and to enhance agricultural practices.

\section{DATA AND METHODOLOGY}

In this study, monthly accumulated precipitation and maximum and minimum temperatures data from 35 meteorological stations located in north and eastern Argentina were used. The region of study corresponds to the south of the La Plata Basin, which is the rainfed agricultural production region of the country (Fig. 1). The data covers the period 1961-2008 and was obtained through the CLARIS LPB database (Penalba et al. 2014). The main sub-basins of the region are the Paraná, Uruguay and Paraguay rivers, which constitute the main natural waterways for transportation and hydropower generation (Fig. 1).

The SPI was used to assess meteorological deficit or excess conditions, considering only precipitation changes. This

In the framework of the European Community's CLARIS-LPB project (www.claris-eu.org), both Work Packages 5 (WP5) and 6 (WP6) focused on evaluating the different processes and future projection of extreme climate events in the LPB. While WP6 analyzed the large-scale climate processes associated with extreme hydroclimatic conditions over LPB and its local interactions (Cavalcanti et al. 2015), WP5 evaluated the capability of regional climate model simulations to reproduce mean climate conditions (Solman et al. 2013) and created an ensemble of regional climate change scenarios with the aim of understanding future changes in precipitation and temperature and their implications for extreme events (Sánchez et al. 2015). The use of regional climate models allowed an understanding of the complexity of the interaction between land surface and atmosphere over the region, in view of the scarcity of observations. The aim of this research is to evaluate the link between extreme rainfall and the hydric condition of the soil, using observational data from the southern La Plata Basin, and to analyze the synindex quantifies the number of standard deviations that the accumulated rainfall deviates from the climatological average of a location. The SPI is computed by fitting a probability density function to the frequency distribution of precipitation accumulated over the time scale of interest (typically 1 to $24 \mathrm{mo}$ ). This is performed separately for each month of the year and for each location in space. Following Penalba \& Rivera (2015), the 2-parameter gamma probability density function was used, which appropriately fits the accumulated precipitation in the study region for time scales between 1 and 12 mo. This was verified through the Anderson-Darling goodness-of-fit test (Anderson \& Darling 1952) for a confidence level of $95 \%$. From the 420 goodness-offit tests for each time scale - 12 mo multiplied by 35 meteorological stations $->93 \%$ of the cases showed significant fits to a 2-parameter gamma distribution. As an example, Fig. 2 shows the percentage of stations, together with the number of stations, with significant fits per month for the time scale of $1 \mathrm{mo}$. Only July showed $<90 \%$ of the stations with significant 


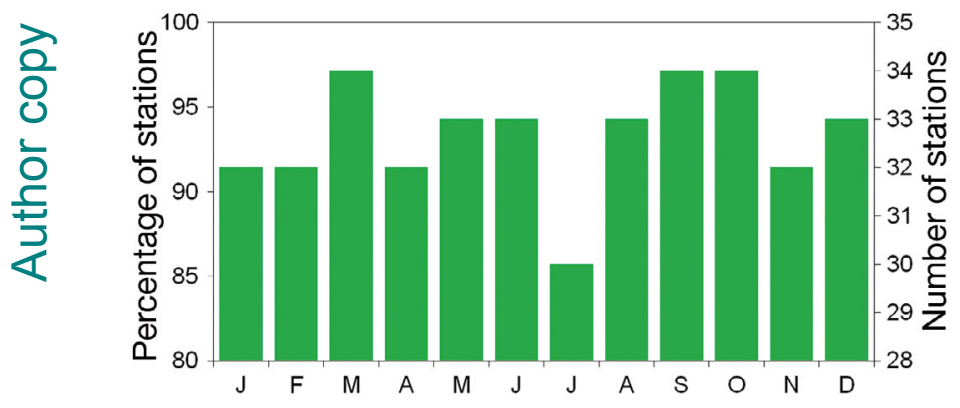

Fig. 2. Percentage of meteorological stations (left axis) and number of stations (right axis) with significant fits to the gamma probability density function for each month of the year for a time scale of $1 \mathrm{mo}$

Table 1. Standardized Precipitation Index (SPI) categorization

\begin{tabular}{|lc|}
\hline Category & SPI value \\
\hline Extremely wet & $\geq 2.0$ \\
Severely wet & 1.5 to 1.99 \\
Moderately wet & 1.0 to 1.49 \\
Mild wet & 0 to 0.99 \\
Mild drought & -0.99 to 0 \\
Moderately dry & -1.49 to -1.0 \\
Severely dry & -1.99 to -1.5 \\
Extremely dry & $\leq-2.0$ \\
\hline
\end{tabular}

fits, meaning that during this month, 30 stations showed significant fits to the gamma distribution.

The 12 probability density functions were translated to 12 cumulative density functions. Given that the gamma distribution is undefined for $x=0$, the relative frequency of precipitation containing zero values $(q)$ was considered for the cumulative density function:

$$
H(x)=q+(1-q) G(x)
$$

where $G(x)$ is the gamma cumulative density function. Thus, $H(x)$ represents a mixed distribution function of zeros and continuous precipitation amounts (Wu et al. 2007). Finally, an equi-probability transformation from the cumulative density functions to the standard normal distribution with a mean of 0 and a variance of 1 was performed in order to obtain the SPI. Dry and wet events were categorized according to the classification system used by Lloyd-Hughes \& Saunders (2002) (Table 1).

The monthly water balance was calculated using the methodology proposed by Thornthwaite \& Mather (1957) and Pascale \& Damario (1977), taking into account the field capacity (FC) of the soil (Forte Lay \& Spescha 2001). At a monthly scale $(t)$, the crops suffer hydric stress when the precipitation (PP) is less than the potential evapotranspiration (PET), computed as deficit conditions (DEF). On the other hand, when the precipitation is higher than the potential evapotranspiration and the water storage in the soil reaches the field capacity, the surplus causes excess conditions (EXC).

Under these considerations, the monthly hydric condition (HC) of the soil was estimated as the difference between excess and deficit (more details in Pántano et al. 2014):

$$
\begin{gathered}
\mathrm{HC}(t)=\operatorname{EXC}(t)-\operatorname{DEF}(t) \\
\operatorname{DEF}(t)=\left\{\begin{array}{cl}
\operatorname{PET}(t)-\operatorname{AET}(t) & \text { if } \operatorname{PP}(t)<\operatorname{PET}(t) \\
0 & \text { if } \operatorname{PP}(t)>\operatorname{PET}(t)
\end{array}\right.
\end{gathered}
$$

$\operatorname{EXC}(t)=$

$\left\{\begin{array}{l}\mathrm{S}(t-1)+\mathrm{PP}(t)-\mathrm{PET}(t)-\mathrm{FC} \text { if } \mathrm{PP}(t)-\mathrm{PET}(t)+\mathrm{S}(t-1)>\mathrm{FC} \\ \text {. }\end{array}\right.$

where AET is the actual evapotranspiration and $S$ is the storage of water in soil.

To represent observed circulation at low levels, the dominant sea level pressure circulation types (CT) found by Bettolli \& Penalba (2014) were used. These CT were based on daily mean sea level pressure (SLP) fields from NCEP-DOE Reanalysis 2 (Kanamitsu et al. 2002) over a domain that includes the Pacific and the Atlantic Oceans and the Andes Mountains, geographical features that have a significant influence on the circulation over South America. These CT were then defined employing a principal component analysis combined with a cluster analysis. The classification resulted in 5 summer CT (labeled as CTsi, i: 1 to 5) and 7 winter CT (labeled as CTwi, i: 1 to 7) (Fig. 3).

In order to compare the spatial coherence of both indexes (SPI and HC), Taylor diagrams (Taylor 2001) were constructed for each index, and dry and wet conditions. These diagrams quantify the degree of statistical similarity between 2 fields (in this study, between spatial distribution of each condition - dry or wet-and the composite of them) considering the correlation coefficient, the standard deviation and the root mean squared difference (RMSD).

\subsection{SPI time scale selection}

The time scale over which precipitation deficits accumulate becomes extremely important, and functionally separates different types of drought (McKee et al. 1993). For example, according to Edwards \& 

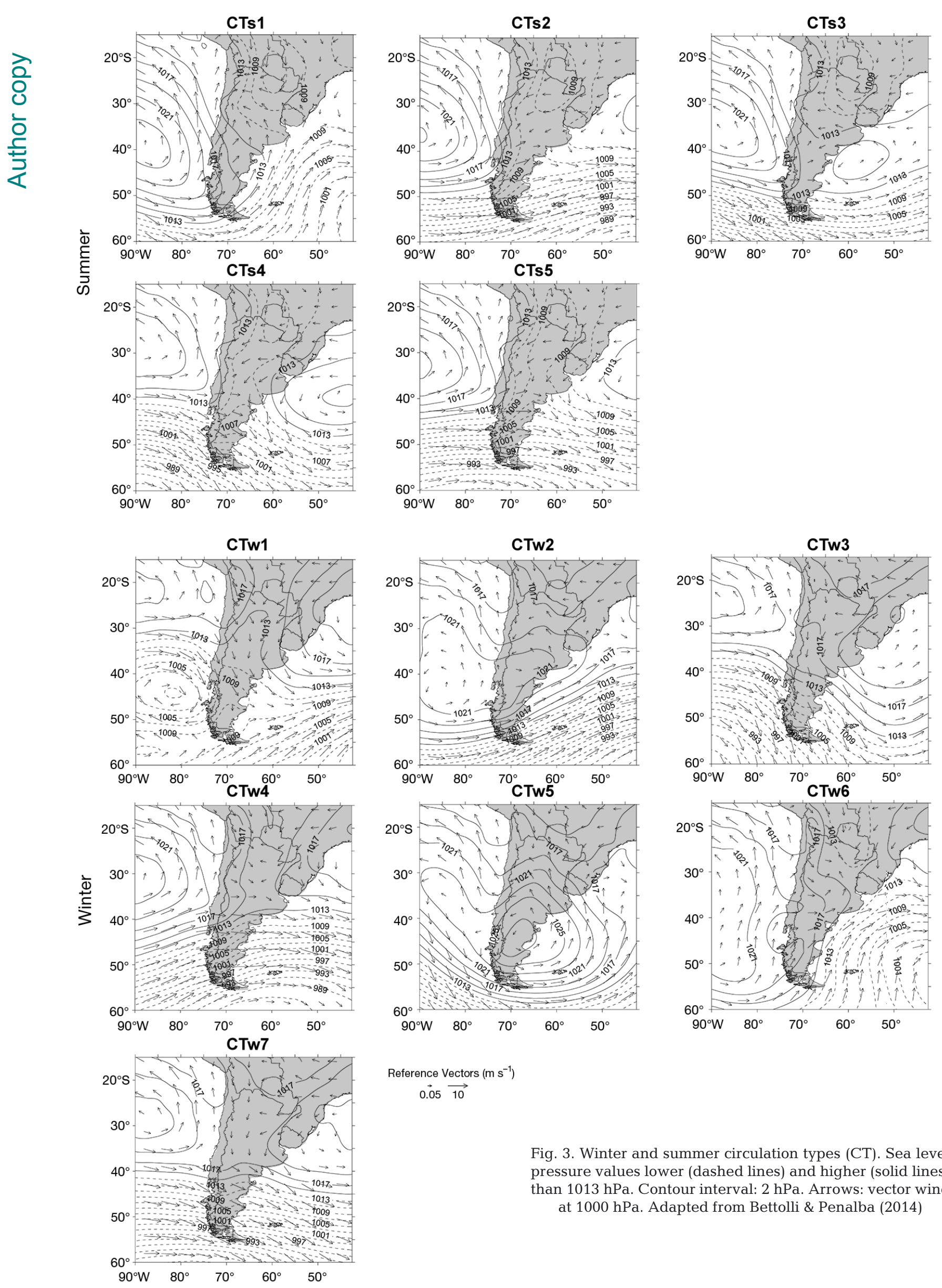

Reference Vectors $\left(\mathrm{m} \mathrm{s}^{-1}\right)$

$0.05 \overrightarrow{10}$

Fig. 3. Winter and summer circulation types (CT). Sea level pressure values lower (dashed lines) and higher (solid lines) than $1013 \mathrm{hPa}$. Contour interval: $2 \mathrm{hPa}$. Arrows: vector wind at $1000 \mathrm{hPa}$. Adapted from Bettolli \& Penalba (2014) 
McKee (1997), time scales of 3 and 12 mo (SPI3 and SPI12) identify shortterm and medium-term droughts, respectively, while time scales around 48 mo can be useful for characterizing long-term droughts. Shortterm droughts are likely to impact agricultural production, while longterm droughts describe deficiencies in the reservoirs and groundwater levels. In this paper, we tested the SPI based on time scales between 1 and $12 \mathrm{mo}$; hence, this provides relevant information to both agricultural and hydrological interests (Guttman 1999, Lloyd-Hughes \& Saunders 2002). In

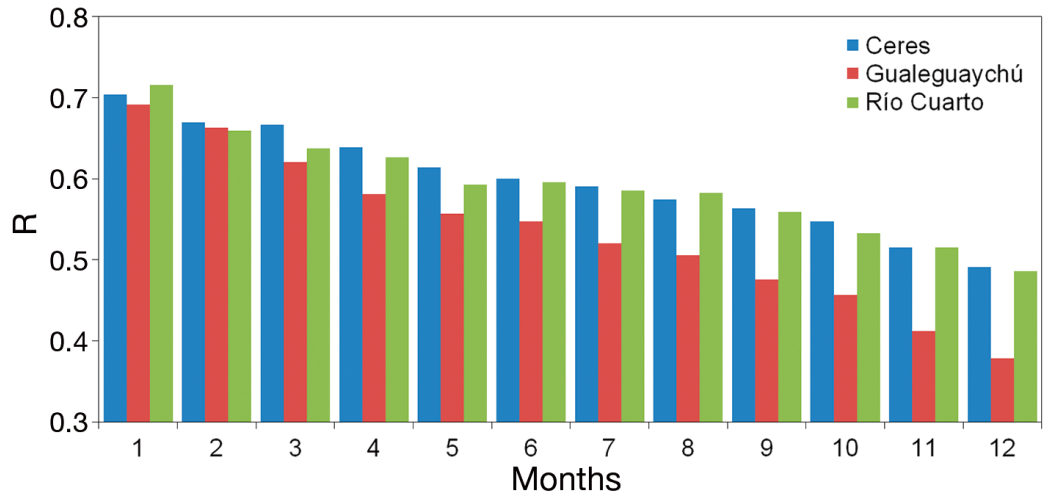

Fig. 4. Correlation coefficient between the Standardized Precipitation Index (SPI) at different time scales and the hydric condition for 3 reference locations (Ceres 29.7 $7^{\circ} \mathrm{S}, 61.8^{\circ} \mathrm{W}$; Gualeguaychú $33^{\circ} \mathrm{S}, 58.4^{\circ} \mathrm{W}$; Río Cuarto $\left.33.1^{\circ} \mathrm{S}, 64.1^{\circ} \mathrm{W}\right)$ order to assess which SPI time scale best responds to the hydric condition in the study region, the Pearson correlation between the SPI and the $\mathrm{HC}$ series for the 35 stations were calculated. The strongest link was obtained for a 1 mo time scale (SPI1), which means that the hydric condition reacts quickly to precipitation changes (Fig. 4). Given that variations in $\mathrm{HC}$ are better represented by precipitation at a 1 mo time scale, the following analysis will consider only the SPI1 to assess meteorological excess and drought. The acronym SPI will be used in the rest of the text although it refers to the SPI1 index. The results are in agreement with the findings of Spennemann et al. (2015), who analyzed the relationship between precipitation and soil moisture for several soil layers and different land surface model simulations over the La Plata Basin and found that time scales between 1 and 9 mo show better relationships with soil moisture anomalies over the study area.

\section{RESULTS}

\subsection{Defining regional extremes}

Once the SPI time scale was established, excess conditions (a wet month) and drought conditions (a dry month) were defined as occurring when the SPI value was $>1.0$ or $<-1.0$, respectively (Rivera \& Penalba 2014). In order to assess the degree of spatial coherence in the region, the percentage of meteorological stations under wet or dry conditions was calculated. Fig. 5 shows these temporal evolutions for

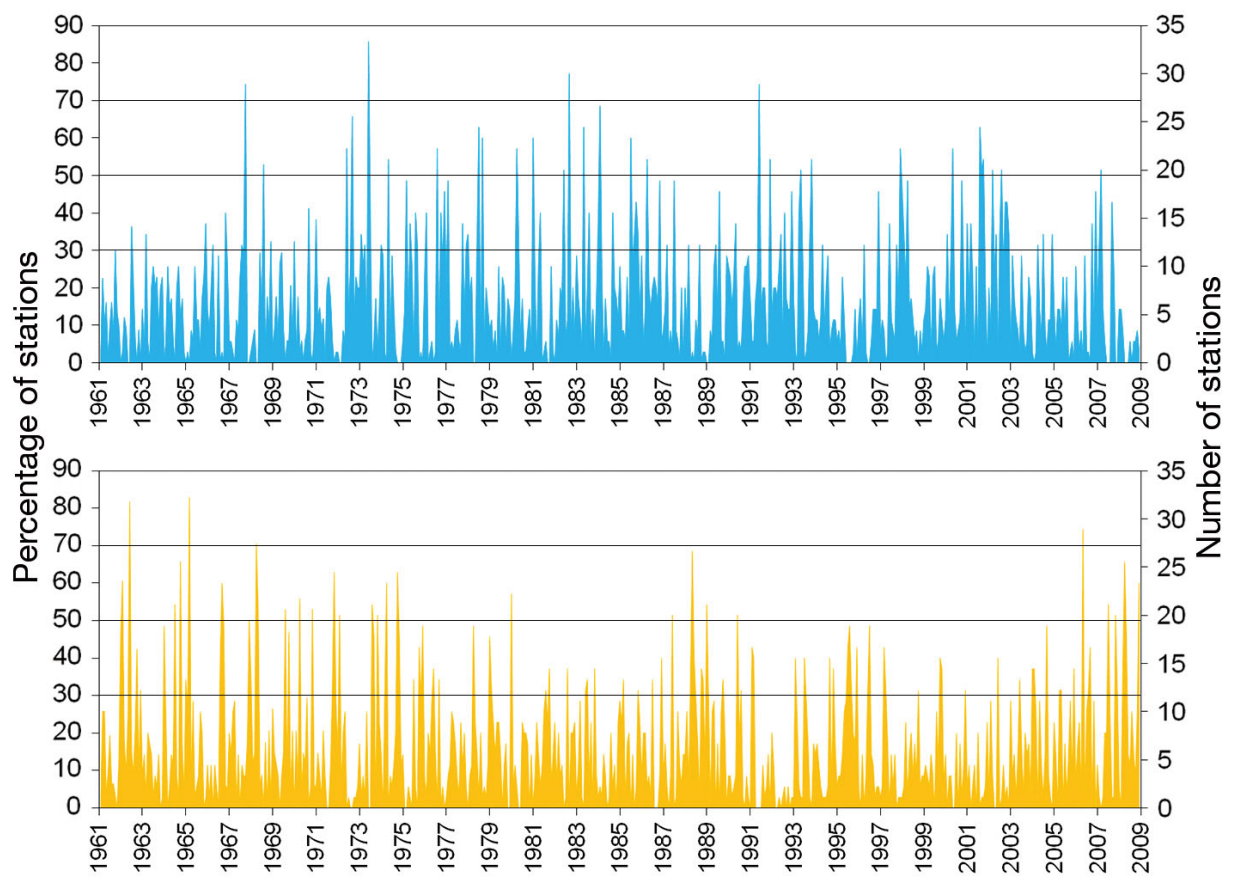

Fig. 5. Temporal evolution of the percentage (left axis) and number (right axis) of meteorological stations with (blue) wet and (orange) dry conditions during 1961 to 2008 
the study period. A strong temporal variability with alternating periods of dryness and wetness can be seen. Periods with a large percentage of locations affected by excess conditions were observed during the second half of the 1970s and during the 1980s, while large-scale droughts were observed mostly during the 1960s and the first half of the 1970s. This could be partially modulated by multidecadal variations related to the Pacific Decadal Oscillation (PDO, Mantua et al. 1997), with El Niño-like conditions during the wet years and La Niña-like conditions during the dry years. This is consistent with several studies performed over central Argentina that considered precipitation (Compagnucci et al. 2002, Penalba et al. 2005, Agosta \& Compagnucci 2008, Agosta \& Cavagnaro 2010), streamflow (Carril et al. 1997, Compagnucci \& Vargas 1998), and snowpack variations over the Central Andes (Masiokas et al. 2006). The occurrence of widespread dry conditions during the last years of the 1980s (Minetti et al. 2007, Rivera \& Penalba 2014) and after 2006 are also evident, in agreement with the development of La Niña conditions.

In order to evaluate the regional extent of wet and dry conditions, 3 different thresholds were considered: 30,50 , and $70 \%$ of stations under wet or dry conditions (hereafter called local, sub-regional, and regional wet or dry months, respectively). Table 2 shows the number of months with a percentage of locations above the selected thresholds for dry and wet cases, together with the month of occurrence. Due to the standardization of precipitation, the total numbers of months with dry and wet conditions are approximately the same. Although dry conditions tend to cover great extensions in response to the occurrence of anomalous anticyclonic circulation (Barrucand et al. 2007, 2014, Alessandro 2008), the results for the analyzed period indicate that the occurrence of regional wet or dry events is equally likely.

Examining the threshold of $70 \%$ in Fig. 5, regional dry months were observed in June 1962, March 1965, April 1968, and May 2006, while the months with regional wet events were October 1967, June 1973, September 1982, and June 1991. The absence of a month or set of months that stands out in terms of the frequency of dry and wet conditions (Table 2) is in line with the findings of Rivera \& Penalba (2015)
Table 2. Number of months with dry and wet conditions for the selected spatial thresholds. Square brackets: percentage of cases with respect to the total number of months (48 for each of the months and 576 for the total)

\begin{tabular}{|c|c|c|c|c|c|c|}
\hline Month & $\begin{array}{l}\text { Local } \\
(30 \%)\end{array}$ & $\begin{array}{c}\text { Dry } \\
\text { Sub- } \\
\text { regional } \\
(50 \%)\end{array}$ & $\begin{array}{c}\text { Regional } \\
(70 \%)\end{array}$ & $\begin{array}{l}\text { Local } \\
(30 \%)\end{array}$ & $\begin{array}{c}\text { Wet- } \\
\text { Sub- } \\
\text { regional } \\
(50 \%)\end{array}$ & $\begin{array}{c}\text { Regional } \\
(70 \%)\end{array}$ \\
\hline Jan & 8 [16.7] & 2 & & 8 [16.7] & 1 & \\
\hline Feb & 6 [12.5] & 2 & & $7[14.6]$ & 1 & \\
\hline Mar & 6 [12.5] & 1 & 1 & 7 [14.6] & 2 & \\
\hline Apr & $8[16.7]$ & 4 & 1 & $8[16.7]$ & 2 & \\
\hline May & 5 [10.4] & 3 & 1 & $10[20.8]$ & 4 & \\
\hline Jun & $9[18.7]$ & 3 & 1 & $8[16.7]$ & 4 & 2 \\
\hline Jul & $8[16.7]$ & 2 & & $7[14.6]$ & 2 & \\
\hline Aug & $8[16.7]$ & 2 & & 9 [18.7] & 4 & \\
\hline Sep & $7[14.6]$ & 1 & & 10 [20.8] & 4 & 1 \\
\hline Oct & 12 [25.0] & 2 & & 11 [22.9] & 2 & 1 \\
\hline Nov & 10 [20.8] & 4 & & $5[10.4]$ & 1 & \\
\hline Dec & 9 [18.7] & 2 & & 11 [22.9] & 2 & \\
\hline Total & 96 [16.7] & 28 & 4 & 101 [17.6] & 29 & 4 \\
\hline
\end{tabular}

Table 3. Same as Table 2 for the Southern Hemisphere seasons

\begin{tabular}{|c|c|c|c|c|c|c|}
\hline \multirow{2}{*}{ Season } & \multicolumn{3}{|c|}{$\longrightarrow$ Dry } & \multicolumn{3}{|c|}{ - Wet } \\
\hline & $\begin{array}{l}\text { Local } \\
(30 \%)\end{array}$ & $\begin{array}{l}\text { Sub- } \\
\text { regional } \\
(50 \%)\end{array}$ & $\begin{array}{l}\text { Regional } \\
1 \quad(70 \%)\end{array}$ & $\begin{array}{l}\text { Local } \\
(30 \%)\end{array}$ & $\begin{array}{l}\text { Sub- } \\
\text { regional } \\
(50 \%)\end{array}$ & $\begin{array}{l}\text { Regional } \\
(70 \%)\end{array}$ \\
\hline Summer & $23[16.0]$ & 6 & 0 & 26 [18.1] & 4 & 0 \\
\hline Autumn & $19[13.2]$ & 8 & 3 & $25[17.4]$ & 8 & 0 \\
\hline Winter & $25[17.4]$ & 7 & 1 & $24[16.7]$ & 10 & 2 \\
\hline Spring & $29[20.1]$ & 7 & 0 & $26[18.1]$ & 7 & 2 \\
\hline Total & $96[16.7]$ & 28 & 4 & $101[17.6]$ & 29 & 4 \\
\hline
\end{tabular}

over 7 regions of southern South America. Table 3 shows the number of months with dry and wet conditions for each austral season considering the selected spatial thresholds. Regional dry conditions were found during the autumn months, and local dry conditions tended to occur mainly during spring. Subregional dry conditions had a similar number of seasonal occurrences (Table 3), although the monthly distribution showed a maximum during April and November and minimum during March and September (Table 2). It is interesting to note that the seasons with high risk of dry conditions (autumn and spring) are the seasons where the annual precipitation cycle for the region peaks (Penalba \& Vargas 2008). This result could be attributed to the interannual variability of precipitation over the region that can shift the occurrence of the peak in the annual precipitation cycle. Regarding wet months, sub-regional occur- 


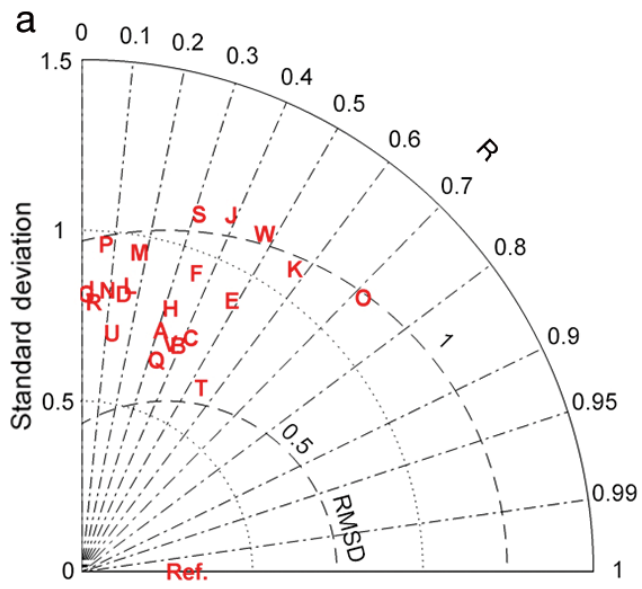

C

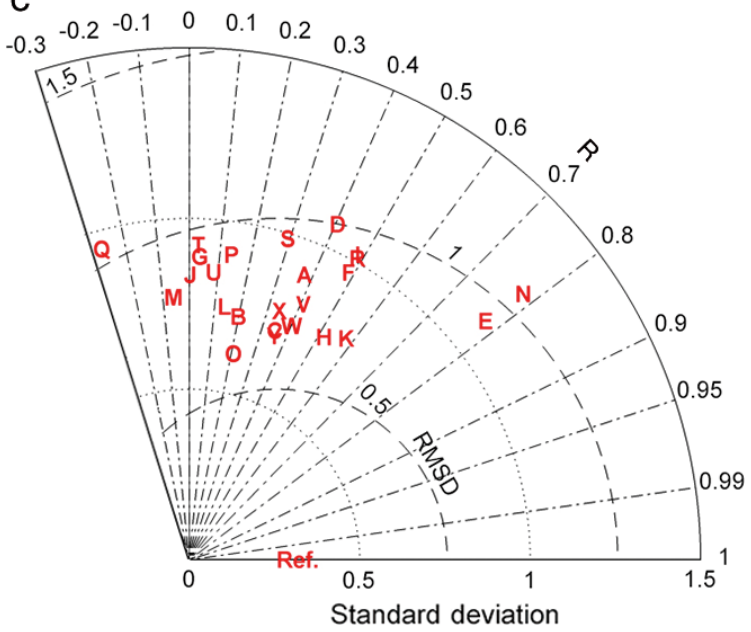

b

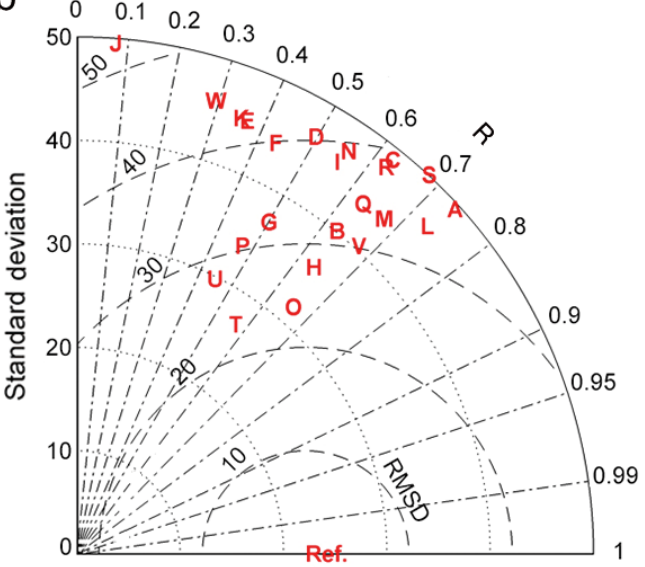

d

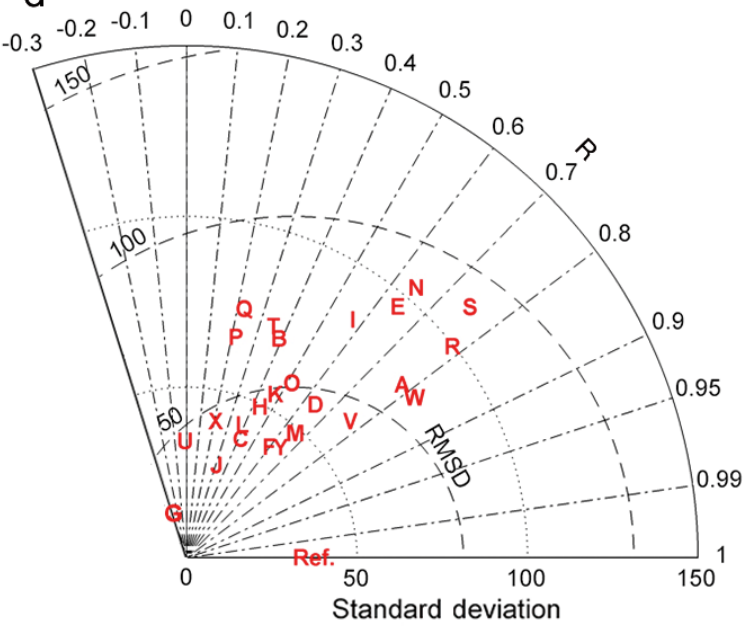

Fig. 6. Taylor diagrams of the spatial pattern of summer sub-regional dry and wet conditions. (a,b) Dry months for (a) the Standardized Precipitation Index (SPI) and (b) hydric condition (HC, mm). (c,d) wet months for (c) the SPI and (d) HC. Letters: each of the analyzed cases, 1 month per letter (see the Appendix for more details). Dashed lines: values of the root mean squared difference. Ref. is the composite spatial pattern

rence was more likely during the autumn and winter months (Table 3). This latter result is relevant from the agronomical point of view, given that soil water recharge during autumn is crucial to allow the crops to handle the scarce winter precipitation, which is almost half of the values recorded in summer (Penalba \& Vargas 2004, Reboita et al. 2010). Local wet events tended to show a heterogeneous pattern at both monthly and seasonal scales, with slight differences in the frequency of occurrence. The regional wet events occurred during winter and spring.

\subsection{Spatial coherence between $\mathrm{HC}$ and SPI indices}

While the SPI is a good indicator of dry and wet meteorological conditions, the index does not take into account local aspects relevant for agriculture, such as evaporation, water storage, and soil type. Therefore, it is relevant to analyze the behavior of the HC and to compare it with the SPI for the 3 different spatial thresholds described in Section 3.1.

In order to outline and summarize the spatial structure of the large number of available cases, Figs. 6 $\& 7$ show comparisons of the spatial patterns of local wet and dry conditions for summer and winter months, respectively, summarized in Taylor diagrams. We selected the local extreme condition, given that it provides a reasonable number of months to analyze in comparison with the sub-regional and regional cases. For both indices, regardless of the season and condition, a large dispersion can be observed between the different spatial patterns. Furthermore, comparing the Taylor diagrams of the SPI and HC for each one of the dry and wet conditions, it is not possible to detect a coherent structural pattern 

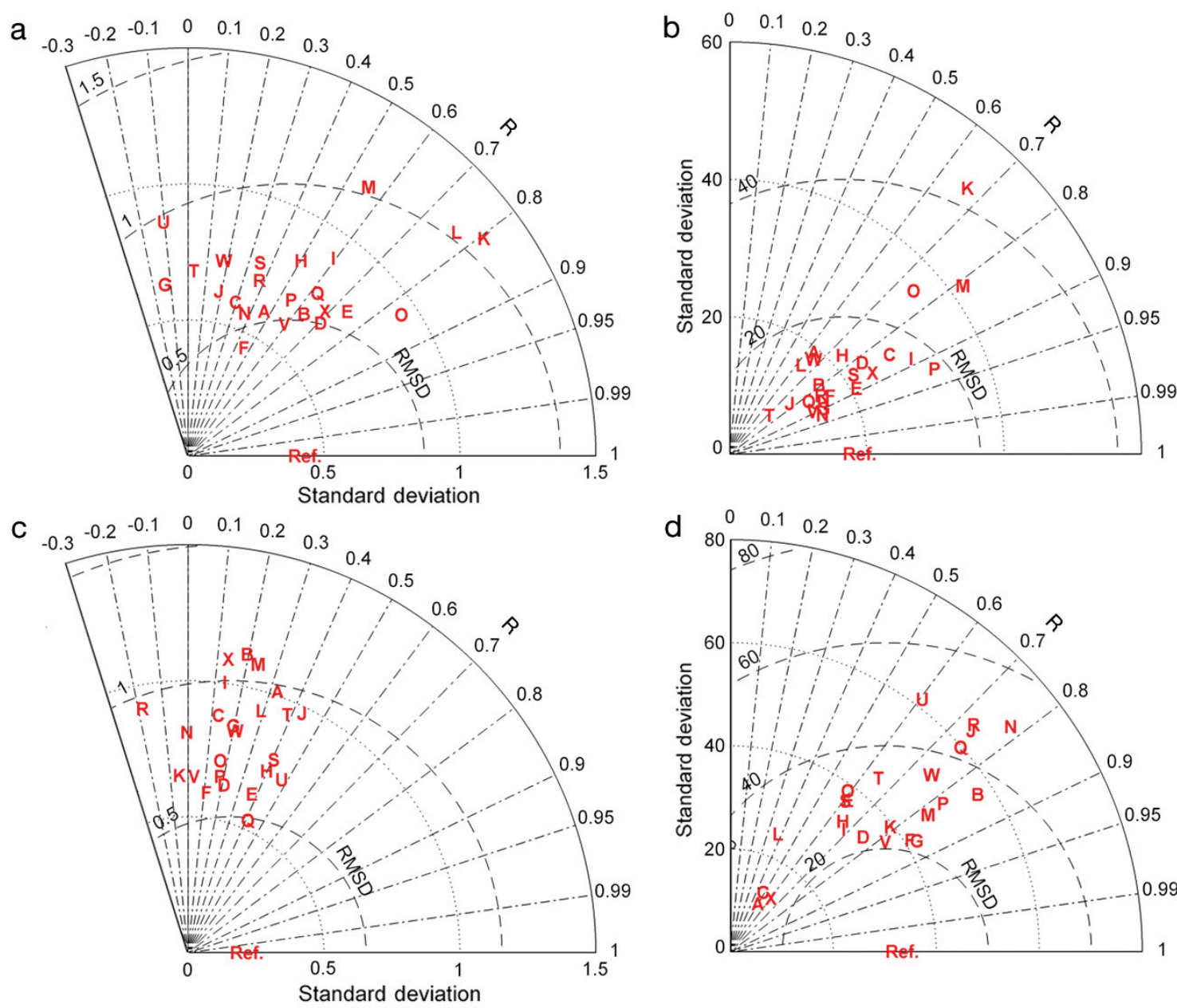

Fig. 7. Same as Fig. 6 for $(a, b)$ dry winter months and $(c, d)$ wet winter months

that coincides for the SPI and HC. That is, although the clouds of points are dispersed there is no correspondence between the SPI and HC. These results highlight the diversity of wet and dry conditions in the region, not only when considering only 1 index SPI or HC - but also when considering the spatial correspondence or coherence between the 2 indices. These characteristics affirm the complexity of the problem and the impossibility of synthesizing or grouping the extreme events. Therefore, for both indices, the composite of these events would not be a representative field for any single event nor for the whole set of events. The results indicate that a unique representative group for the whole region cannot be identified at a local scale. Similar results were found for autumn and spring spatial patterns of local wet and dry conditions (not shown).

In order to analyze the spatial coherence between the HC and SPI indices, the spatial behavior during dry and wet months was assessed for different thres- holds. We selected 2 months under local and regional dry and wet conditions. These months were January 2004 and February 2007 for the case of local dry and wet months, respectively, and June 1962 and June 1991 for the case of regional dry and wet months, respectively. It is worthwhile mentioning that these months correspond to the summer season for the local cases and the winter season for the regional cases. The main synoptic features of the regional drought of 1962, analyzed by Malaka \& Nuñez (1980), caused losses of $>80 \%$ of the crop yields over southern Buenos Aires province (Carbone et al. 2004). The wet case of 1991 was associated with El Niño, which caused flooding of the Paraná, Paraguay and Uruguay rivers (see Fig. 1 for location of rivers) (Gentile 1994, Latrubesse \& Brea 2008). Fig. 8 shows the spatial distribution of the SPI categories, together with the behavior of the $\mathrm{HC}$ for the selected local dry and wet months. The stations that were affected by drought conditions in January 2004 are located north 

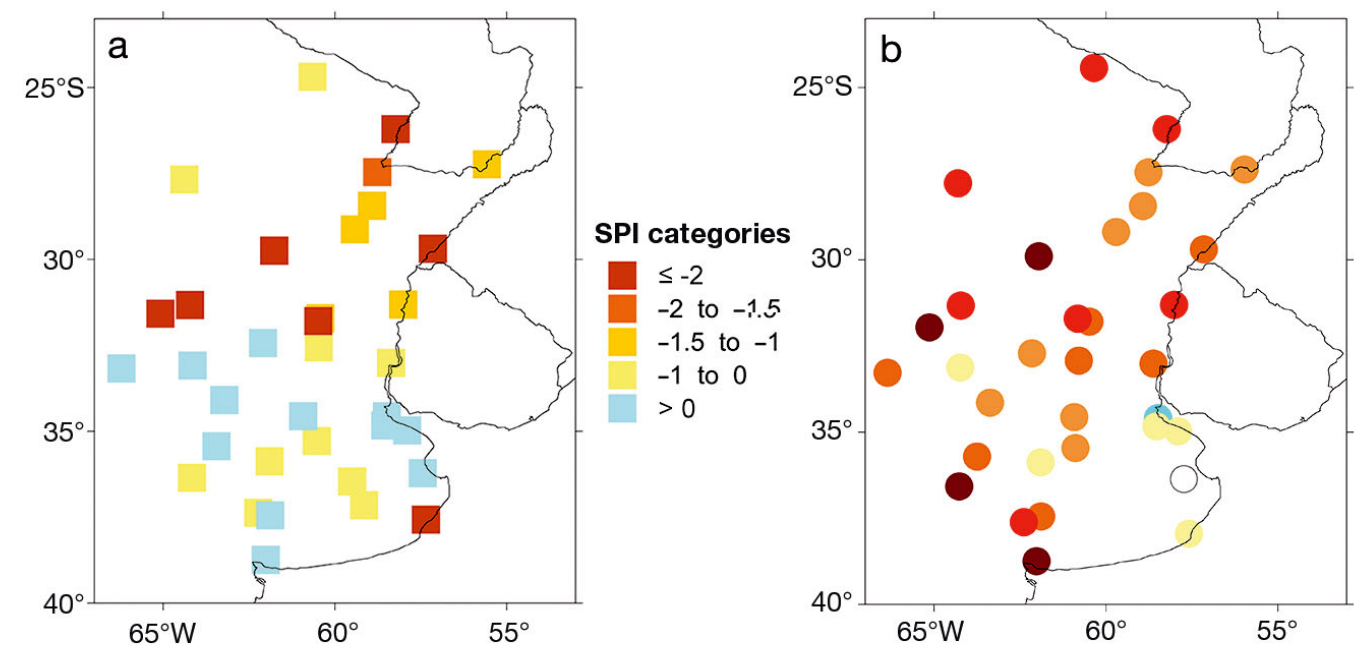

HC categories (mm)

$\leq-150$

-100 to -75

-75 to -50

-50 to -25

-25 to -1

-1 to 1

$>1$
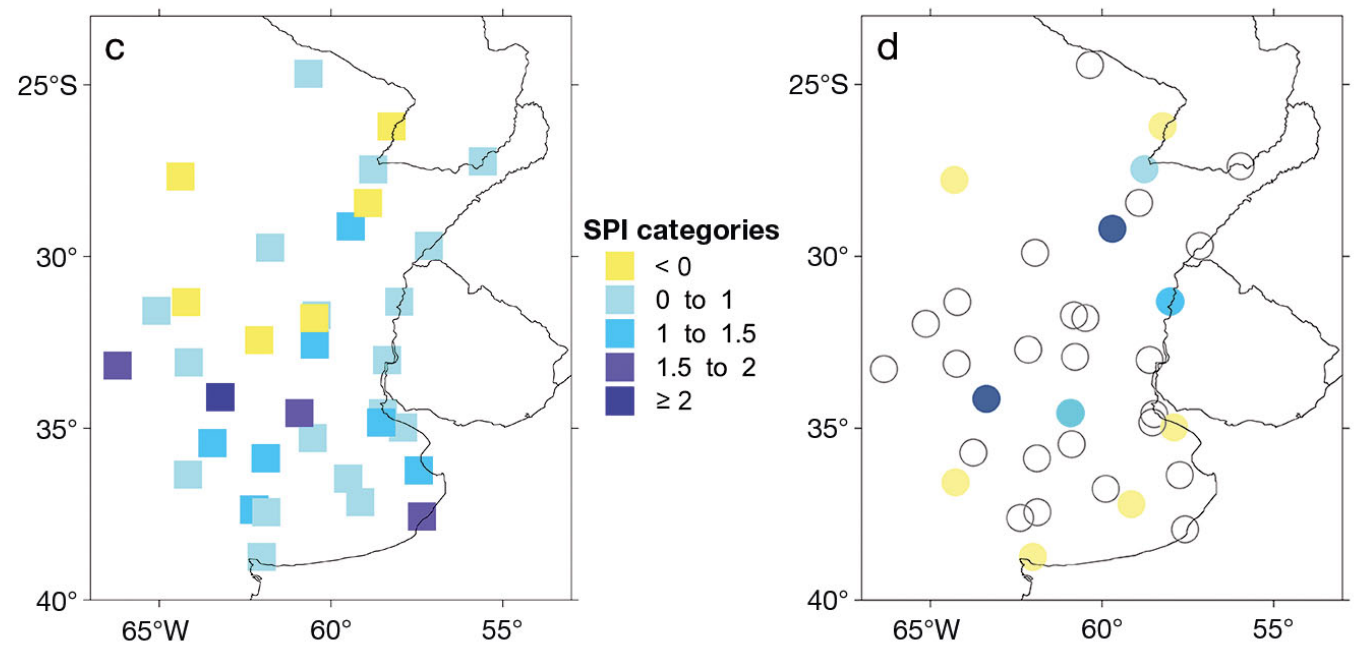

HC categories (mm)

$<-1$

-1 to 1

1 to 25

25 to 50

50 to 75

75 to 100

100 to 150

150 to 200

$\geq 200$

Fig. 8. Spatial distribution of the $(\mathrm{a}, \mathrm{c})$ Standardized Precipitation Index (SPI) and $(\mathrm{b}, \mathrm{d})$ hydric condition (HC) during the selected local (a,b) dry (January 2004) and (c,d) wet (February 2007) conditions

of $33^{\circ} \mathrm{S}$, mostly along the Paraná and Uruguay rivers (Fig. 8a). This is in agreement with the behavior of the HC (Fig. 8b), which presented absolute deficit values higher than the deficit conditions characteristic of January (Pántano et al. 2014). In general, summer months were characterized by deficit conditions due to high potential evapotranspiration. That is why the stations located over the southwestern portion of the Humid Pampas also showed deficit conditions, which the SPI classified as mild drought or wet conditions. In the case of local wet conditions, the SPI indicated that the wet area was restricted to the south of $32^{\circ} \mathrm{S}$, affecting the Humid Pampas, although mildwet conditions were observed in some of the stations in the northern portion of the study area (Fig. 8c). The HC values classified only 5 stations as being under excess conditions (Fig. 8d), since high precipitation was not generally enough to reach field capac- ity. However, absolute values of deficit conditions were lower than the median HC for February (not shown) and some stations presented equilibrium conditions $(\mathrm{HC} \approx 0)$, meaning that for those stations, precipitation was higher than potential evapotranspiration.

For the case of the regional dry conditions, Fig. 9a shows the spatial distribution of the SPI categories during June 1962. Five stations located on the eastern portion of the domain were affected by extreme drought conditions, while 14 stations experienced severe drought, most of them located in the Buenos Aires province. Regarding the HC (Fig. 9b), scarce precipitation caused deficit conditions even in the east. In general, during winter months, both potential evapotranspiration and precipitation are reduced in almost the whole region; therefore, deficit conditions characterize the west of the region while equilibrium 

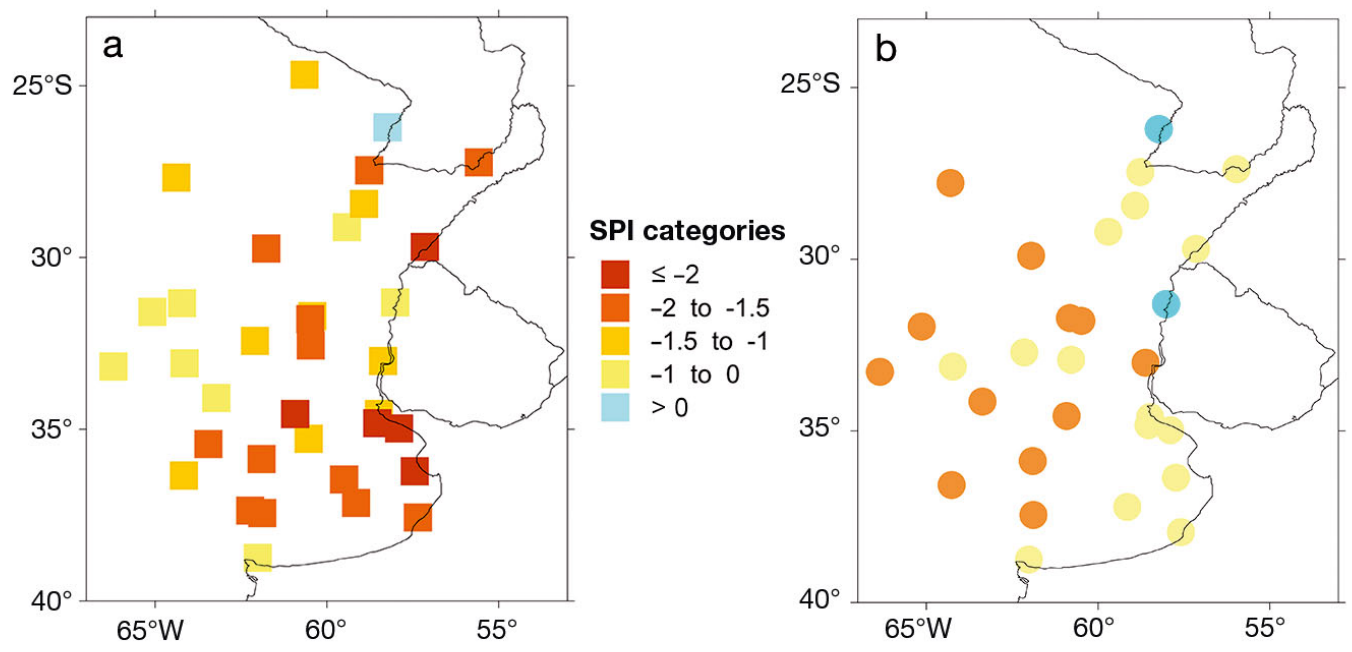

HC categories $(\mathrm{mm})$

$\leq-150$

-150 to -100

-100 to -75

-75 to -50

-50 to -25

-25 to -1

-1 to 1

$>1$
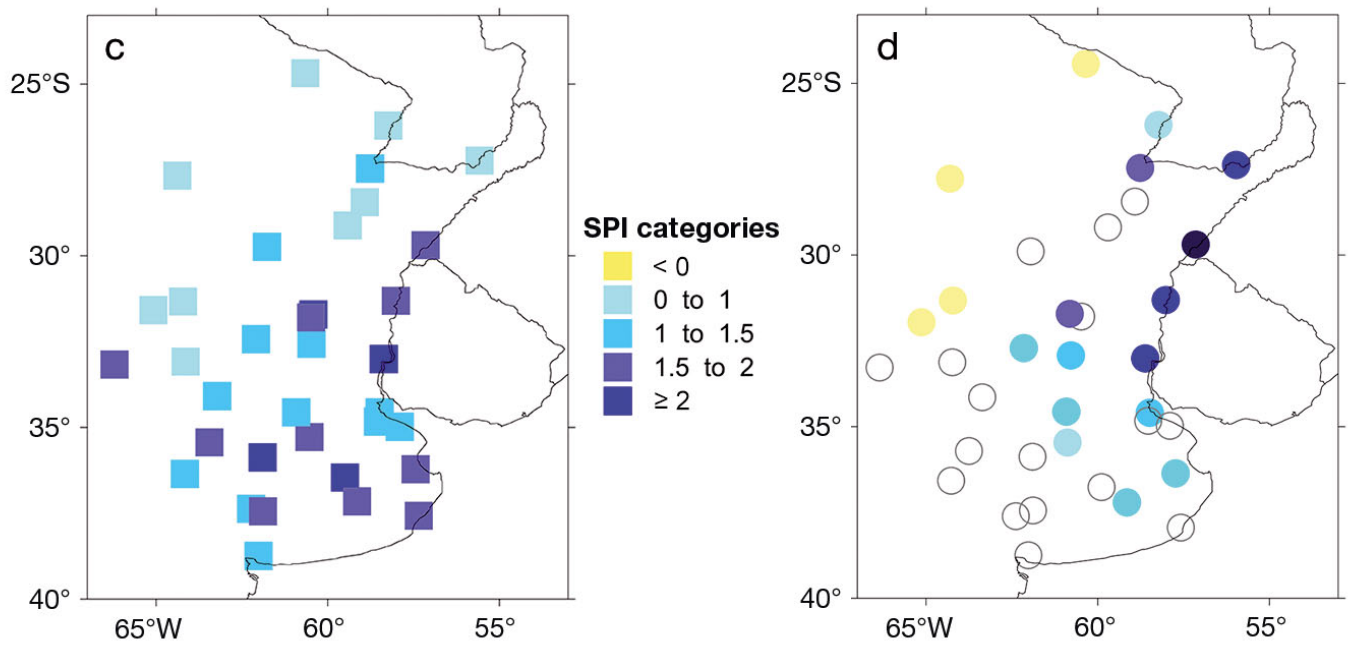

HC categories $(\mathrm{mm})$

$<-1$

-1 to 1

1 to 25

25 to 50

50 to 75

75 to 100

100 to 150

150 to 200

$\geq 200$

Fig. 9. Spatial distribution of the $(\mathrm{a}, \mathrm{c})$ Standardized Precipitation Index (SPI) and $(\mathrm{b}, \mathrm{d})$ hydric condition (HC) mm during the selected regional (a,b) dry (June 1962) and (c,d) wet (June 1991) conditions

or excess conditions characterize the eastern part (Pántano et al. 2014). For June 1962, deficit conditions were also influenced by low soil water storage in March 1962 (not shown). During June 1991, the SPI classified all the stations as wet (Fig. 9c). The stations with severe and extreme wet conditions (SPI values $>1.0$ ) are located in the southern portion of the La Plata Basin. Looking at the spatial behavior of the $\mathrm{HC}$, excess conditions were observed in the east, along the Uruguay river basin (Fig. 9d). Even though intense rainfall events were recorded during June 1991, equilibrium hydric conditions were observed in the soil in the stations located in the center since deficit conditions at the beginning of the month did not allow storage to reach field capacity. However, the region was under wetter conditions, since western stations are characterized by deficit conditions, as explained above.

\subsection{Atmospheric circulation during extreme events}

The spatial structure of the extreme months of the SPI and the related $\mathrm{HC}$ showed a high variability and different spatial scales. Therefore, the circulation associated with each extreme month will vary depending on the sub-region where the extreme event occurs.

The frequency of days related to each CT presented in Fig. 3 was calculated considering the months defined as dry or wet. The standardized monthly frequency of each $\mathrm{CT}$, that is, the deviation from its climatological value relativized to its standard deviation, was analyzed. The aim was to evaluate if it is possible to associate any CT in particular with the dry or wet conditions. The analysis was conducted for the 4 extreme months described in the Section 3.2. 
Table 4. Standardized monthly frequencies of circulation types (CT) for the studied extreme events. Bold: standardized anomalies exceeding one standard deviation in absoulte value

\begin{tabular}{|lrrrrrrrr|}
\hline Winter & Year & CTw1 & CTw2 & CTw3 & CTw4 & CTw5 & CTw6 & CTw7 \\
\hline Jun & 1991 & $\mathbf{2 . 0}$ & $\mathbf{1 . 1}$ & -0.6 & 0.0 & $\mathbf{- 1 . 0}$ & 0.1 & $\mathbf{- 1 . 1}$ \\
Jun & 1962 & -0.6 & -0.7 & $\mathbf{- 1 . 2}$ & $\mathbf{1 . 0}$ & $\mathbf{- 1 . 0}$ & $\mathbf{- 1 . 2}$ & $\mathbf{1 . 8}$ \\
& & & & & & & & \\
Summer & Year & CTs1 & CTs2 & CTs3 & CTs4 & CTs5 & & \\
\hline Jan & 2004 & 0.0 & $\mathbf{- 1 . 3}$ & 0.3 & $\mathbf{1 . 1}$ & 0.2 & & \\
Feb & 2007 & 0.3 & $\mathbf{1 . 3}$ & -0.8 & $\mathbf{- 1 . 4}$ & 0.5 & & \\
\hline
\end{tabular}

voring the southeast wind component over the southern region (Penalba et al. 2013). The combination of both CT favors humidity convergence from the north-northeast and southeast, especially toward the southern part of the region studied, where maximum SPI values were located (Fig. 9c). Moreover, CTw1 and CTw2 have opposite effects on surface temperature anomalies in the region (Penalba et al. 2013), so their combination or joint occurrence would not contribute to significant anomalies in temperature, and therefore, the HC and SPI presented similar behavior at

Dry conditions dominated in January 2004, particularly north of $33^{\circ} \mathrm{S}$ (Fig. 8a,b). During this month, CTs4 showed frequencies that exceed 1 standard deviation from its climatological value and CTs2 instead showed negative anomalies in its frequency (Table 4). CTs4 represents an intensification and expansion of the southern Atlantic Ocean anticyclone, which favors stability at low levels and warm advection from the northeast. This pattern can be significantly associated with dry and warm days in the central Pampas region (Penalba et al. 2013). CTs2 is characterized by a low pressure perturbation over the continent and a weakening of the Atlantic anticyclone that could be related to a cold front affecting the region. CTs2 significantly favors rain and heavy rain $\left(>10 \mathrm{~mm} \mathrm{~d}^{-1}\right)$ in the central area of the studied region (Bettolli \& Penalba, 2014). The combined anomalies in the frequency of occurrence of these 2 circulation patterns and their effects on precipitation and temperature are in line with the dry conditions determined by the SPI and HC field.

Local wet conditions determined by SPI values were located towards the southern half of the region during February 2007 (Fig. 8c). This situation is consistent with the higher than normal frequencies of CTs2 and the lower than normal frequencies of CTs4, as is shown in Table 4. In terms of circulation patterns, February 2007 showed the opposite structure to January 2004.

June 1991 was characterized by an anomalous circulation in terms of CT frequency. During this month, CTw1 and CTw2 showed a high frequency of occurrence, while CTw5 and CTw7 showed a low frequency of occurrence, exceeding 1 standard deviation in absolute value (Table 4). CTw1 is characterized by a cyclonic perturbation that dominates the circulation over the southern South Pacific Ocean which, combined with the high pressure over the Atlantic Ocean, favors humid advection from the north and northeast. In CTw2, a high pressure system extends towards the south, entering over the continent and fa- some stations (Fig. 9). Climatologically, CTw7 is the most frequent circulation pattern during winter, and significantly favors dry days in the region (Bettolli \& Penalba 2014). The low frequency of CTw7 is consistent with the results of Bettolini \& Penalba (2014).

June 1962 showed a completely different CT frequency pattern (Table 4). The extremely anomalous circulation during this month was dominated by CTw7 and CTw4, where $15 \mathrm{~d}$ corresponded to CTw7 and $11 \mathrm{~d}$ to CTw4. These 2 patterns induce higher maximum temperature values over the region (Penalba et al. 2013) and favor dry days in the Pampas region (Bettolli \& Penalba 2014), which generate stable low-level conditions related to a high pressure system that extends from the Atlantic Ocean to the center of the continent. Clear skies and the northern/northeastern component of low-level winds lead to the warmer maximum temperatures associated with these 2 patterns. Regional HC and SPI responses are directly linked to this anomalous circulation feature.

\section{CONCLUSIONS}

The La Plata Basin in southern South America is a system sensitive to climate variability and change, with potential consequences for water resources and agricultural activities in the region. Here, the association between extreme rainfall and soil hydric condition on the one hand and the synoptic features that favor the occurrence of these extreme events on the other is analyzed over the south of the La Plata Basin. This aspect, using observational data, is considered in the CLARIS LPB Project framework in the context of Work Package 6, and complements the studies carried out with regional climate model simulations.

The results show that the hydric conditions of soil respond to precipitation anomalies in a relatively short time scale. Furthermore, the spatial coherence 
observed between the $\mathrm{HC}$ and the SPI at a 1 mo time scale suggests the effectiveness of this index in the analysis of monthly extreme soil hydric conditions. It was shown that the correlation coefficient between the HC and the SPI decreased as the time scale considered for the accumulation of precipitation increased.

Local and regional dry conditions tended to occur during the spring and autumn months, respectively. This result is relevant from the agronomic point of view, given that the soil water recharge during these months is crucial to enable the crops to cope with the high potential evapotranspiration during summer and the scarce winter precipitation.

According to the water balance used in this study, deficit conditions depend on the difference between precipitation and potential evapotranspiration, while excess conditions are observed when water storage reaches field capacity. Therefore, for months under low precipitation, both the SPI and HC show deficit conditions during summer, when potential evapotranspiration is characterized by higher values. For months with high precipitation, the SPI indicates wet conditions while the HC increases, although excess conditions are not necessarily observed.

A classification of daily fields of sea level pressure was used to examine if dry and wet months could be distinguished by atmospheric circulation patterns. The analysis suggests that there is no exact match between circulation types and extreme events, though only some aspects of circulation were considered in this work. There are other aspects that could be taken into account when studying extreme events, such as land-atmosphere interactions, other circulation and temperature variables, and temporal-spatial processes. However, during extreme months, the atmospheric circulation represented by the sea level pressure patterns showed completely anomalous features depending on each particular extreme event and its spatial extension in the studied region. The exceptional high or low frequencies of certain patterns induce precipitation and temperature anomalies that could explain SPI and HC features.

Acknowledgements. The authors thank the responsible editor and the anonymous reviewers for their valuable suggestions that improved the manuscript. This work was supported by the European Community's Seventh Framework Programme (FP7/2007-2013) under Grant Agreement No. 212492: CLARIS LPB. 'A Europe-South America Network for Climate Change Assessment and Impact Studies in La Plata Basin' and the projects UBA-20020100100789 from the University of Buenos Aires and CONICET PIP 227 from the National Council of Scientific and Technical Research.

\section{LITERATURE CITED}

Agosta EA, Cavagnaro M (2010) Variaciones interanuales de la precipitación de verano y el rendimiento del cultivo de la vid en Mendoza. Geoacta 35:1-16

Agosta EA, Compagnucci RH (2008) Procesos atmosféricos/oceánicos de baja frecuencia sobre la cuenca sudoeste del Atlántico Sur y la variabilidad de la precipitación en el centro-oeste de Argentina. Geoacta 33:21-31

Alessandro AP (2008) Anomalías de circulación atmosférica en 500 y $1000 \mathrm{hPa}$ asociada a la sequía producida en la Argentina durante enero de 2003 a marzo de 2004. Rev Bras Meteorol 23:12-29

Anderson TW, Darling DA (1952) Asymptotic theory of certain 'goodness of fit' criteria based on stochastic processes. Ann Math Stat 23:193-212

> Barrucand MG, Vargas WM, Rusticucci MM (2007) Dry conditions over Argentina and the related monthly circulation patterns. Meteorol Atmos Phys 98:99-114

Barrucand MG, Vargas WM, Bettolli ML (2014) Warm and cold dry months and associated circulation in the humid and semi-humid Argentine region. Meteorol Atmos Phys 123:143-154

Bettolli ML, Penalba OC (2014) Synoptic sea level pressure patterns - daily rainfall relationship over the Argentine Pampas in a multi-model simulation. Meteorol Appl 21: 376-383

Bidegain M, Skansi M, Penalba O, Quintana J, Aceituno P (2010) Southern South America (in 'State of the Climate in 2009'). Bull Am Meteorol Soc 91:S150-S151

Bidegain M, Skansi M, Penalba O, Quintana J (2011) Southern South America (in 'State of the Climate in 2010'). Bull Am Meteorol Soc 92:S190-S192

Boulanger JP, Leloup J, Penalba OC, Rusticucci MM, Lafon F, Vargas WM (2005) Observed precipitation in the Paraná-Plata hydrological basin: long-term trends, extreme conditions and ENSO teleconnections. Clim Dyn 24:393-413

Carbone ME, Piccolo MC, Scian BV (2004) Análisis de los períodos secos y húmedos en la cuenca del arroyo Claromecó, Argentina. Papeles de Geografía 40:25-35

Carril AF, Menéndez CG, Nuñez M (1997) Climate change scenarios over the South American region: An intercomparison of coupled general atmosphere-ocean circulation models. Int J Climatol 17:1613-1633

Castañeda M, Barros V (2001) Tendencias de la precipitación en oeste de la Argentina. Meteorológica 26:5-23

> Cavalcanti IFA (2012) Large scale and synoptic features associated with extreme precipitation over South America: a review and case studies for the first decade of the 21st century. Atmos Res 118:27-40

Cavalcanti IFA, Carril AF, Penalba OC, Grimm AM and others (2015) Precipitation extremes over La Plata Basin review and new results from observations and climate simulations. J Hydrol (Amst) 523:211-230

Compagnucci RH, Vargas WM (1998) Inter-annual variability of the Cuyo rivers' streamflow in the Argentinean Andean mountains and ENSO events. Int J Climatol 18: 1593-1609

> Compagnucci RH, Agosta EA, Vargas WM (2002) Climatic change and quasi-oscillations in Central-West Argentina summer precipitation. Main features and coherent behaviour with Southern African region. Clim Dyn 18: 421-435

Edwards DC, McKee TB (1997) Characteristics of 20th cen- 
tury drought in the United States at multiple time scales. Atmospheric Science Paper No. 634, Climatology Report, No. 97-2, Department of Atmospheric Sciences, Colorado State University, Fort Collins, CO

Ereño C (ed) (2011) CLIVAR Exchanges No. 57 (Vol 16 No. 3). Special issue - La Plata Basin. Indigo Press, Southampton

Espinoza JC, Ronchail J, Lengaigne M, Quispe N and others (2013) Revisiting wintertime cold air intrusions at the east of the Andes: propagating features from subtropical Argentina to Peruvian Amazon and relationship with large-scale circulation patterns. Clim Dyn 41:1983-2002

Forte Lay JA, Spescha L (2001) Método para la estimación de la climatología del agua edáfica en las provincias pampeanas de la Argentina. Rev Arg Agrometeorol 1: 67-74

Gentile E (1994) El Niño no tiene la culpa: vulnerabilidad en el Noreste Argentino. Desastres y Sociedad 3:68-85

Guttman NB (1999) Accepting the Standardized Precipitation Index: a calculation algorithm. J Am Water Resour Assoc 35:311-322

IPCC (2013) Climate change 2013: the physical science basis. Contribution of Working Group I to the Fifth Assessment Report of the Intergovernmental Panel on Climate Change. Stocker TF, Qin D, Plattner GK, Tignor M and others (eds) Cambridge University Press, Cambridge

Kanamitsu M, Ebisuzaki W, Woollen J, Yang SK, Hnilo JJ, Fiorino M, Potter GL (2002) NCEP-DOE AMIP-II Reanalysis (R-2). Bull Am Meteorol Soc 83:1631-1643

Krepper CM, Zucarelli V (2010) Climatology of water excess and shortages in the La Plata Basin. Theor Appl Climatol 102:13-27

Latrubesse E, Brea D (2008) Floods in Argentina. In: Latrubesse E (ed) Geomorphology of natural hazards and human exacerbated disasters in Latin America. Elsevier, Amsterdam, p 333-349

Lloyd-Hughes B, Saunders MA (2002) A drought climatology for Europe. Int J Climatol 22:1571-1592

Malaka I, Nuñez S (1980) Aspectos sinópticos de la sequía que afectó a la República Argentina en el año 1962. Geoacta 10:1-21

- Mantua NJ, Hare SR, Zhang Y, Wallace JM, Francis RC (1997) A Pacific interdecadal climate oscillation with impacts on salmon production. Bull Am Meteorol Soc 78: 1069-1079

> Masiokas MH, Villalba R, Luckman BH, Le Quesne C, Aravena JC (2006) Snowpack variations in the central Andes of Argentina and Chile, 1951-2005: large-scale atmospheric influences and implications for water resources in the region. J Clim 19:6334-6352

McKee TB, Doesken NJ, Kleist J (1993) The relationship of drought frequency and duration to time scales. Proc 8th Conf Applied Climatology, Anaheim, CA, American Meteorological Society, p 179-184

Minetti JL, Vargas WM, Poblete AG, Acuña LR, Casagrande G (2003) Non-linear trends and low frequency oscillations in annual precipitation over Argentina and Chile, 1931-1999. Atmósfera 16:119-135

Minetti JL, Vargas WM, Vega B, Costa MC (2007) Las sequías en la Pampa Húmeda: impacto en la productividad del maíz. Rev Bras Meteorol 22:218-232

Pántano V, Spescha L, Penalba O, Murphy G (2014) Influencia de la variabilidad de la temperatura y la precipitación en el agua del suelo, en la región oriental de secano de Argentina. Meteorológica 39:21-36
Pascale JY, Damario EA (1977) El Balance Hidrológico Seriado y su utilización en estudios agroclimáticos. Rev Fac Agron La Plata 53:15-34

Penalba OC, Rivera JA (2015) Regional aspects of future precipitation and meteorological drought characteristics over Southern South America projected by a CMIP5 multimodel ensemble. Int J Climatol, doi:10.1002/joc.4398

Penalba OC, Rivera JA (2013) Future changes in drought characteristics over Southern South America projected by a CMIP5 multi-model ensemble. Am J Clim Chang 2: 173-182

> Penalba OC, Robledo F (2010) Spatial and temporal variability of the frequency of extreme daily rainfall regime in the La Plata Basin during the 20th century. Clim Change 98:531-550

Penalba OC, Vargas W (2004) Interdecadal and Interannual variations of annual and extreme precipitation over central-northeastern Argentina. Int J Climatol 24:1565-1580

Penalba O, Vargas W (2008) Variability of low monthly rainfall in La Plata Basin. Meteorol Appl 15:313-323

Penalba OC, Beltran A, Messina C (2005) Monthly rainfall in central-eastern Argentina and ENSO. A comparative study of rainfall forecast methodologies. Rev Bras Agrometeorol 13:49-61

Penalba OC, Bettolli ML, Krieger PA (2013) Surface circulation types and daily maximum and minimum temperatures in southern La Plata Basin. J Appl Meteorol Climatol 52:2450-2459

Penalba OC, Rivera JA, Pántano VC (2014) The CLARIS LPB database: constructing a long-term daily hydrometeorological dataset for La Plata Basin, southern South America. Geosci Data J 1:20-29

> Popescu I, Brandimarte L, Perera MSU, Peviani M (2012) Assessing residual hydropower potential of the La Plata Basin accounting for future user demands. Hydrol Earth Syst Sci 16:2813-2823

Reboita MS, Alonso Gan M, Da Rocha RP, Ambrizzi T (2010) Regimes de precipitação na América do Sul: uma revisão bibliográfica. Rev Bras Meteorol 25:185-204

Rivera JA, Penalba OC (2014) Trends and spatial patterns of drought affected area in southern South America. Climate 2:264-278

Rivera J, Penalba O (2015) El Niño/La Niña events as a tool for regional drought monitoring in southern South America. In: Andreu J, Solera A, Paredes-Arquiola J, HaroMonteagudo D, van Lanen H (eds) Drought: research and science-policy interfacing. CRC Press/Balkema, Leiden, p 293-299

Ruscica RC, Sörensson AA, Menéndez CG (2014) Pathways between soil moisture and precipitation in southeastern South America. Atmos Sci Lett 16:267-272

Sánchez E, Solman S, Remedio ARC, Berbery H and others (2015) Regional climate modelling in CLARIS LPB: a concerted approach towards twentyfirst century projections of regional temperature and precipitation over South America. Clim Dyn 45:2193-2212

Seiler RA, Hayes M, Bressan L (2002) Using the Standardized Precipitation Index for flood risk monitoring. Int $\mathrm{J}$ Climatol 22:1365-1376

- Seneviratne SI, Corti T, Davin EL, Hirschi M and others (2010) Investigating soil moisture-climate interactions in a changing climate: a review. Earth Sci Rev 99:125-161

Solman SA, Menéndez CG (2003) Weather regimes in the South American sector and neighbouring oceans during winter. Clim Dyn 21:91-104 
Solman SA, Sanchez E, Samuelsson P, da Rocha RP and others (2013) Evaluation of an ensemble of regional climate model simulations over South America driven by the ERA-Interim reanalysis: model performance and uncertainties. Clim Dyn 41:1139-1157

Sörensson AA, Menéndez CG (2011) Summer soil-precipitation coupling in South America. Tellus 63:56-68

Spennemann PC, Rivera JA, Saulo AC, Penalba OC (2015) A comparison of GLDAS soil moisture anomalies against the standardized precipitation index and multisatellite estimations over South America. J Hydrometeorol 16: 158-171

Taylor KE (2001) Summarizing multiple aspects of model performance in a single diagram. J Geophys Res 106: 7183-7192

Thornthwaite CW, Mather JR (1957) Instructions and tables for computing potential evapotranspiration and water balance. In: Publications in Climatology, Vol 10. Laboratory of Climatology, Drexel Institute of Technology, Centerton, NJ, p 185-311

World Bank (2015) World development indicators 2015. World Bank, Washington, DC

Wu H, Svoboda MD, Hayes MJ, Wilhite DA, Wen F (2007) Appropriate application of the Standardized Precipitation Index in arid locations and dry seasons. Int $\mathrm{J}$ Climatol 27:65-79

\section{Appendix}

Letters corresponding to dates in Taylor diagrams in Figs. 6 \& 7

\begin{tabular}{|c|c|c|c|c|c|c|c|}
\hline \multicolumn{2}{|c|}{ Dry conditions } & \multicolumn{2}{|c|}{ Wet conditions } & \multicolumn{2}{|c|}{ Dry conditions } & \multicolumn{2}{|c|}{ Wet conditions } \\
\hline \multicolumn{2}{|c|}{ Letter Date } & \multicolumn{2}{|c|}{ Letter Date } & \multicolumn{2}{|c|}{ Letter Date } & \multicolumn{2}{|c|}{ Letter Date } \\
\hline \multicolumn{4}{|c|}{ Summer months } & \multicolumn{4}{|c|}{ Winter months } \\
\hline A & January 1962 & A & December 1965 & $\mathrm{~A}$ & June 1962 & $\mathrm{~A}$ & July 1962 \\
\hline B & February 1962 & $\mathrm{~B}$ & December 1968 & B & July 1964 & $\mathrm{~B}$ & August 1967 \\
\hline $\mathrm{C}$ & December 1962 & $\mathrm{C}$ & January 1970 & $\mathrm{C}$ & August 1966 & $\mathrm{C}$ & August 1968 \\
\hline $\mathrm{D}$ & January 1964 & $\mathrm{D}$ & January 1971 & $\mathrm{D}$ & August 1969 & $\mathrm{D}$ & June 1972 \\
\hline $\mathrm{E}$ & January 1965 & $\mathrm{E}$ & February 1973 & $\mathrm{E}$ & August 1973 & $\mathrm{E}$ & June 1973 \\
\hline $\mathrm{F}$ & December 1967 & $\mathrm{~F}$ & January 1974 & $\mathrm{~F}$ & July 1975 & $\mathrm{~F}$ & July 1973 \\
\hline $\mathrm{G}$ & January 1968 & G & February 1976 & G & June 1976 & G & August 1975 \\
\hline $\mathrm{H}$ & February 1972 & $\mathrm{H}$ & December 1976 & $\mathrm{H}$ & August 1981 & $\mathrm{H}$ & August 1976 \\
\hline I & December 1975 & I & February 1977 & I & August 1982 & I & June 1978 \\
\hline $\mathrm{J}$ & January 1979 & $\mathrm{~J}$ & December 1977 & $\mathrm{~J}$ & June 1983 & $\mathrm{~J}$ & July 1978 \\
\hline $\mathrm{K}$ & February 1979 & $\mathrm{~K}$ & January 1978 & $\mathrm{~K}$ & July 1983 & $\mathrm{~K}$ & June 1982 \\
\hline $\mathrm{L}$ & January 1980 & $\mathrm{~L}$ & January 1981 & $\mathrm{~L}$ & July 1986 & $\mathrm{~L}$ & August 1983 \\
\hline M & December 1986 & $\mathrm{M}$ & January 1984 & $\mathrm{M}$ & June 1987 & $\mathrm{M}$ & July 1985 \\
\hline $\mathrm{N}$ & January 1989 & $\mathrm{~N}$ & February 1984 & $\mathrm{~N}$ & June 1988 & $\mathrm{~N}$ & July 1987 \\
\hline $\mathrm{O}$ & February 1991 & $\mathrm{O}$ & December 1991 & $\mathrm{O}$ & June 1990 & $\mathrm{O}$ & June 1989 \\
\hline $\mathrm{P}$ & February 1993 & $\mathrm{P}$ & December 1992 & $\mathrm{P}$ & August 1990 & $\mathrm{P}$ & August 1989 \\
\hline Q & December 1995 & $\mathrm{Q}$ & December 1996 & Q & July 1993 & $\mathrm{Q}$ & June 1991 \\
\hline $\mathrm{R}$ & December 1900 & $\mathrm{R}$ & December 1997 & $\mathrm{R}$ & July 1995 & $\mathrm{R}$ & June 1992 \\
\hline $\mathrm{S}$ & January 2004 & $\mathrm{~S}$ & January 1998 & $\mathrm{~S}$ & August 1995 & $\mathrm{~S}$ & August 1992 \\
\hline $\mathrm{T}$ & February 2004 & $\mathrm{~T}$ & February 1998 & $\mathrm{~T}$ & June 1996 & $\mathrm{~T}$ & June 1997 \\
\hline $\mathrm{U}$ & December 1905 & $\mathrm{U}$ & February 2000 & $\mathrm{U}$ & July 1996 & $\mathrm{U}$ & August 2001 \\
\hline $\mathrm{V}$ & December 1907 & $\mathrm{~V}$ & January 2001 & $\mathrm{~V}$ & June 2002 & $\mathrm{~V}$ & July 2002 \\
\hline \multirow{4}{*}{\multicolumn{2}{|c|}{ December 1908}} & W & December 2002 & W & June 2003 & W & August 2002 \\
\hline & & $\mathrm{X}$ & December 2004 & $\mathrm{X}$ & August 2006 & $\mathrm{X}$ & July 2004 \\
\hline & & $\mathrm{Y}$ & December 2006 & $\mathrm{Y}$ & July 2007 & & \\
\hline & & $\mathrm{Z}$ & February 2007 & & & & \\
\hline
\end{tabular}

Editorial responsibility: Enrique Sanchez, Toledo, Spain (Guest Editor)
Submitted: June 8, 2015; Accepted: October 26, 2015

Proofs received from author(s): December 22, 2015 